\title{
PEMANFAATAN ABU VULKANIK GUNUNG KELUD SEBAGAI PENGGANTI SEBAGIAN AGREGAT HALUS PADA BETON NORMAL SEBAGAI PENDUKUNG BAHAN AJAR MATA KULIAH TEKNOLOGI BETON
} (PADA MAHASISWA PTB, JPTK, UNS)

\author{
Abdul Rohman Anshory ${ }^{1}$, Sri Sumarni ${ }^{2}$, Roemintoyo ${ }^{3}$ \\ Fakultas Keguruan dan Ilmu Pendidikan, Pendidikan Teknik Bangunan, \\ Universitas Sebelas Maret Surakarta \\ e-mail:aan09safitri@gmail.com
}

\begin{abstract}
The purpose of this study was to determine (1) Effect of volcanic ash in partial replacement of the total fine aggregate of compressive strength and the density of the concrete, (2) resistance to the optimal compression of the concrete (3) optimum density concrete. (4) The teaching material obtained in the course of concrete technology on the effect of volcanic ash on the compressive strength of concrete and normal density. Experimental studies using methods and analytical techniques using a quantitative analysis of regression. Variables in the study were (1) the dependent variable: the strength of concrete in compression and the density of concrete, (2) independent variables: the variation of $0 \%, 10 \%, 15 \%, 20 \%$ and 25\% Volcanic ash from the total weight of the sand. The sampel is in the form of a cylinder with a diameter of $150 \mathrm{~mm}$ and a height of $300 \mathrm{~mm}$. Based on the results of the study concluded that (1) changes in volcanic ash as a partial replacement of the fine aggregate strong overall influence on the compressive strength and density of concrete, (2) the optimal value of compressive strength and the weight of each type of concrete which is the variation of volcanic ash 8,36\% amounted to 23,231 MPa, 11,889\% to $22,919 \mathrm{MPa}$, (3) the value of the optimal concrete mixture as a whole, to namely the variation of volcanic ash 11,889\% (4) in the form of teaching material to supplement teaching materials using Kelud volcanic ash as a partial replacement of fine aggregate on in terms of compressive strength concrete and density.
\end{abstract}

\begin{abstract}
ABSTRAK
Tujuan penelitian ini adalah untuk mengetahui (1) Pengaruh penggunaan abu vulkanik sebagai pengganti sebagian agregat halus terhadap kuat tekan dan berat jenis beton, (2) kuat tekan optimal beton, (3) berat jenis optimal beton. (4) bahan ajar yang didapatkan pada mata kuliah teknologi beton tentang pengaruh abu vulkanik pada kuat tekan dan berat jenis pada beton normal. Penelitian menggunakan metode kuantitatif eksperimen dan teknik analisa menggunakan analisis regresi. Variabel yang mempengaruhi dalam penelitian adalah (1) variabel terikat: kuat tekan beton dan berat jenis beton, (2) variabel bebas: variasi $0 \%, 10 \%, 15 \%, 20 \%$, dan $25 \%$ kebutuhan abu vulkanik dari total berat pasir. Benda uji yang digunakan berupa silinder dengan diameter $150 \mathrm{~mm}$ dan tinggi $300 \mathrm{~mm}$. Berdasarkan hasil penelitian disimpulkan bahwa, (1) variasi abu vulkanik sebagai pengganti sebagian agregat halus berpengaruh kuat terhadap kuat tekan dan berat jenis beton, (2) nilai optimal kuat tekan dan berat jenis beton masing-masing yaitu pada variasi abu vulkanik 8,36\% sebesar 23,231 $\mathrm{MPa}, 11,889 \%$ sebesar 22,919 MPa, (3) nilai campuran beton yang optimal secara keseluruhan yaitu pada variasi abu vulkanik $11,889 \%$, (4) bahan ajar yang berupa suplemen bahan ajar tentang pemanfaatan abu vulkanik gunung Kelud sebagai pengganti sebagian agregat halus pada beton ditinjau dari kuat tekan dan berat jenis.
\end{abstract}

Key words: normal concrete, volcanic ash, compressive strength, density.

\footnotetext{
${ }^{1}$ Mahasiswa Program Studi Pendidikan Teknik Bangunan FKIP UNS

${ }^{2}$ Staf Pengajar Program Studi Pendidikan Teknik Bangunan FKIP UNS

${ }^{3}$ Staf Pengajar Program Studi Pendidikan Teknik Bangunan FKIP UNS
} 


\section{PENDAHULUAN}

Pekerjaan beton berperan sangat penting dalam bidang industri konstruksi. Dapat dikatakan hampir pada setiap bangunan yang didirikan seperti gedung bertingkat, perumahan, jalan, jembatan, bendungan, dan saluran irigasi serta bangunan lainnya selalu memerlukan pekerjaan beton, baik sebagai kebutuhan utama maupun sebagai unsur bahan penunjang.

Beton merupakan bahan kontruksi yang saat ini paling banyak digunakan dalam pembangunan karena memiliki banyak kelebihan diantaranya: beton mudah dibentuk sesuai dengan kebutuhan konstruksi, beton mampu memikul beban yang berat, tahan terhadap api dan biaya perawatannya relatif murah. Karena banyaknya penggunaan beton pada struktur bangunan maka diperlukan penelitianpenelitian yang nantinya dapat menghasilkan produk-produk beton yang berkualitas.

Secara sederhana, beton dibentuk oleh pengerasan campuran antara semen hidrolik (Portland Cement), agregat kasar, agregat halus, dan air. Terkadang ditambahkan pula campuran bahan lain/bahan tambah (admixture) untuk memperbaiki kualitas beton. Campuran yang digunakan dalam pembuatan beton merupakan sumber yang berasal dari alam, khususnya pasir. Dengan demikian, perlu adanya pengembangan teknologi bahan untuk mengurangi hal tersebut dan dapat dijadikan bahan alternatif lain yaitu abu vulkanik. Abu vulkanik merupakan bahan material vulkanik yang disemburkan ke udara saat terjadi letusan gunung berapi. Abu vulkanik mengandung Silika $\left(\mathrm{SiO}_{2}\right)$, Oksigen $\left(\mathrm{O}_{2}\right)$, serta zat-zat lainnya seperti Besi (Fe), Mangan (Mn), Silikat (Si), Aluminium (Al), Kalsium (Ca), Kalium (K), dan Fosfor (P). (Gunawan Budianto: 2014)

Di Indonesia khususnya pulau Jawa terdapat gunung-gunung yang masih aktif. Sebagai contoh gunung merapi yang terletak di Jawa Tengah dan Gunung Kelud yang terletak di Jawa Timur. Kedua gunung tersebut terakhir meletus pada tahun 2014. Abu vulkanik yang keluar akibat letusan dari Gunung Kelud menjadi limbah yang sangat banyak. Pada saat itu, abu vulkanik tersebut belum termanfaatkan dan dapat mengakibatkan pencemaran lingkungan serta membahayakan kesehatan manusia. Apabila abu tersebut dibuang ke sungai akan menyebabkan sedimentasi sungai mengalami kenaikan (Merdeka: 2014). Oleh 
karena itu, untuk meminimalisir dampak yang ditimbulkan oleh abu vulkanik maka perlu upaya pemanfaatan abu vulkanik untuk digunakan menjadi sesuatu yang berguna, salah satunya adalah sebagai pengganti pasir pada campuran beton.

Dari paparan di atas pengembangan beton yaitu beton normal dengan menggunakan abu vulkanik sebagai pengganti sebagian pasir perlu dikenalkan ke masyarakat yaitu dapat digunakan untuk membangun rumah tinggal sederhana serta secara mendalam dikenalkan di dalam dunia perkuliahan khususnya pada mata kuliah Teknologi Beton. Mata kuliah Teknologi Beton merupakan mata kuliah wajib yang harus ditempuh di Program Studi Pendidikan Teknik Bangunan. Di dalam Teknologi Beton membahas tentang jenisjenis, sifat-sifat dan penggunaan bahan dalam kontruksi bangunan. Pembelajaran Teknologi Beton di kampus bertujuan menguasai standar kompetensi yang telah ditetapkan. Teknologi Beton dalam pelaksanaan pendidikan diajarkan di institusi-institusi pendidikan, baik ditingkat Sekolah Menengah Kejuruan (SMK) dan perguruan tinggi khususnya teknik bangunan.

\section{Beton}

Beton adalah campuran antara semen portland atau semen hidrolik yang lain, agregat halus, agregat kasar dan air, dengan atau tanpa bahan tambahan yang membentuk massa padat (SNI-03-28472002).

Menurut Kardiyono Tjokrodimuljo (2004: XII-1) jenis-jenis beton ada 8, yaitu sebagai berikut:
a. Beton normal
b. Beton ringan
c. Beton non pasir
d. Beton kedap air
e. Ferosemen
f. Beton serat
g. Beton siklop
h. Beton hampa (Vacuum Concrete)

2. Abu Vulkanik

Abu vulkanik merupakan mineral batuan vulkanik termasuk material glass yang memiliki ukuran sebesar pasir dan kerikil dengan diameter kurang lebih 2 $\mathrm{mm}$ yang merupakan hasil erupsi gunung berapi. Partikel abu sangat kecil tersebut dapat memiliki penampang lebih kecil dari $0,001 \mathrm{~mm}(1 / 25,000$ th of an inch). Abu vulkanik bukan merupakan produk pembakaran seperti abu terbang yang lunak dan halus seperti hasil pembakaran kayu, daun atau kertas. Abu vulkanik 
memiliki sifat sangat keras dan tidak larut didalam air sehingga seringkali sangat abrasif dan sedikit korosif serta mampu menghantarkan listrik ketika dalam keadaan basah (Bayuseno, 2010).

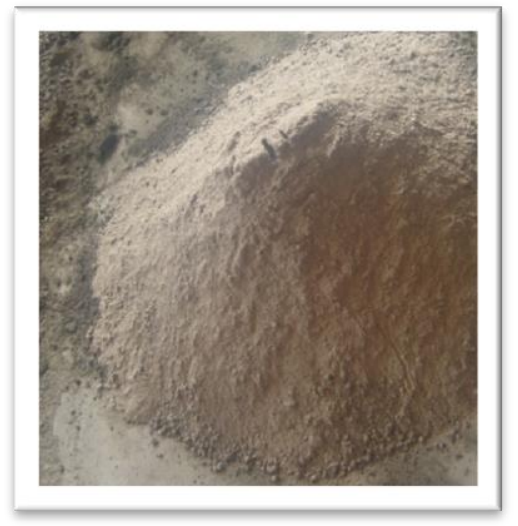

Gambar 1. Abu Vulkanik Gunung Kelud

\section{METODOLOGI PENELITIAN}

1. Bahan

Semen yang digunakan adalah Semen Portland dengan merk Semen Holcim yang telah memenuhi persyaratan dalam spesifikasi SK-SNI-S-04-1989-F.

Pasir yang digunakan adalah pasir Muntilan, Magelang. Hasil uji laboratorium menunjukkan kadar lumpur sebesar 2,60\%, kadar air 11,75\%, kadar zat organic 0-10\%, Bulk Specific Gravity SSD 2,45, modulus kehalusan 3,2 dan tergolong zona I.

$\mathrm{Abu}$ vulkanik yang digunakan adalah abu vulkanik hasil letusan gunung Kelud yang diperoleh di desa Dukuh RT
2/V, Mojolaban, Sukoharjo. Hasil uji laboratorium menunjukkan kadar lumpur sebesar 10,63\%, kadar air 0,33\%, kadar zat organik 10-20\%, Bulk Specific Gravity SSD 2,49, modulus kehalusan 1,5 dan tidak masuk zona gradasi agregat halus. Hasil uji kimia dengan metode XRF menunjukkan $\mathrm{SiO}_{2} 51,57 \%, \mathrm{Al}_{2} \mathrm{O}_{3}$ $16,22 \%, \mathrm{Fe}_{2} \mathrm{O}_{3} 12,52 \%, \mathrm{CaO} 12,17 \%$ dan $\mathrm{MgO} 2,96 \%$.

Kerikil yang digunakan adalah pasir Muntilan, Magelang. Hasil uji laboratorium menunjukkan modulus kehalusan kerikil 3,05 dan Bulk Spesific Gravity SSD 2,46.

Air yang digunakan adalah air yang memenuhi persyaratan SK SNI S-041989-F.

2. Pembuatan Benda Uji

Campuran beton pada penelitian ini menggunakan perbandingan berat $1 \mathrm{Pc}: 2$ Ps : $3 \mathrm{Kr}$ dengan variasi penggantian abu vulkanik sebagai pengganti agregat halus $0 \%, 10 \%, 15 \%, 20 \%$, dan $20 \%$ dari berat total pasir. Proses pembuatannya dengan mencampur semen, pasir, kerikil, dan abu vulkanik sampai rata, selanjutnya menambahkan air secukupnya dan diaduk sampai homogen. Memasukkan adukan tersebut ke dalam cetakan silinder beton dengan diameter $150 \mathrm{~mm}$ dan tinggi 300 
mm, kemudian memadatkan adukan tersebut setiap $1 / 3$ bagian dari tinggi cetakan. Setelah selesai, menunggu selama 24 jam agar beton dari cetakan tersebut siap dibuka dan rendam selama 28 hari.

Benda uji yang dihasilkan berupa beton silinder dengan diameter $150 \mathrm{~mm}$ dan tinggi $300 \mathrm{~mm}$. Jumlah total sampel benda uji silinder beton adalah 25 buah.

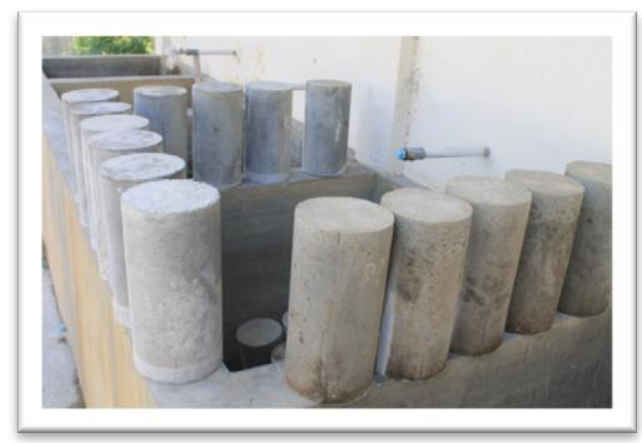

Gambar 2. Benda Uji Silinder Beton

\section{Pengujian}

Benda uji beton silinder yang sudah mengalami perawatan selama 28 hari selanjutnya dilakukan pengujian, meliputi uji kuat tekan dan berat jenis beton.

\section{HASIL DAN PEMBAHASAN}

Hasil pengujian kuat tekan dan berat jenis beton dengan abu vulkanik sebgai pengganti sebagian agegragat halus ditunjukkan pada tabel 1 sebagai berikut:

\begin{tabular}{|c|c|c|}
\hline $\begin{array}{c}\text { Variasi } \\
\text { Abu } \\
\text { Vulkanik }\end{array}$ & $\begin{array}{c}\text { Kuat Tekan Rata- } \\
\text { rata Beton (MPa) }\end{array}$ & $\begin{array}{c}\text { Berat Jenis Rata- } \\
\text { rata Beton }\left(\mathrm{kg} / \mathrm{m}^{3}\right)\end{array}$ \\
\hline $0 \%$ & 21,345 & 2208,82 \\
\hline $10 \%$ & 23,100 & 2246,57 \\
\hline $15 \%$ & 24,209 & 2257,89 \\
\hline $20 \%$ & 17,563 & 2219,77 \\
\hline $25 \%$ & 17,325 & 2203,92 \\
\hline
\end{tabular}

Analisis data menggunakan program computer Statistical Package for the Social Science 16.0 (SPSS 16.0) yaitu dengan uji Regression (Curve Estimation).

Hasil pengujian kuat tekan beton dengan uji linieritas dengan menggunakan program komputer statistik SPSS 16.0 dapat diringkas pada tabel 2 dan gambar 3 berikut ini:

Tabel 2. Hasil Uji Regresi Kuat Tekan Beton

Model Summary and Parameter Estimates Dependent Variable: Kuat Tekan Beton

Model Summary Parameter Estimates
$\mathrm{R}$

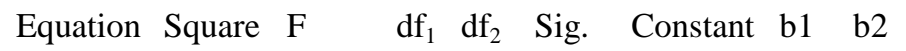
\begin{tabular}{lllllllll} 
Quadratic & .575 & 14.895 & 2 & 22 & .000 & 21.484 & .418 & - \\
\hline
\end{tabular}

The independent variable is Kuat Tekan Beton. 


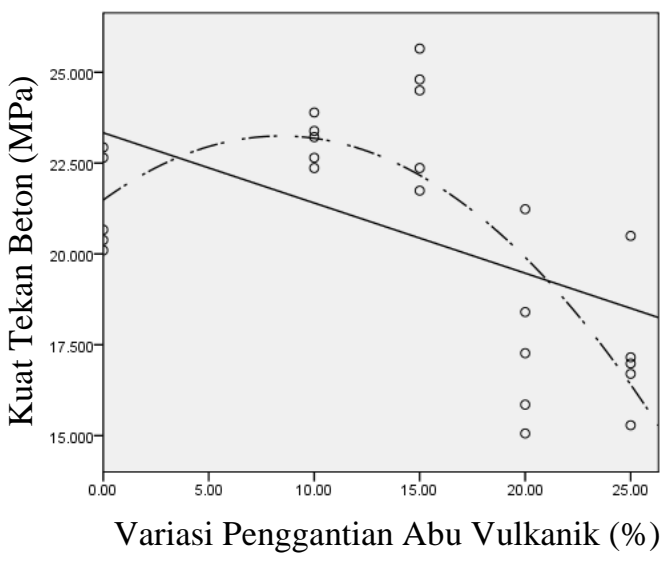

Gambar 3. Pengaruh Penggantian Abu

Vulkanik Gunung Kelud terhadap Kuat Tekan Beton

Berdasarkan tabel 2 dan gambar 3 diperoleh hubungan variasi penggantian abu vulkanik dan kuat tekan beton bernilai signifikan sebesar $0,000<0,05$ yang berarti bahwa data non linier. Untuk keberartian regresi diperoleh $F_{\text {tabel }}$ dengan taraf kesalahan $5 \%, \mathrm{df}_{1}=2$ dan $\mathrm{df}_{2}=22$ sebesar 3,44 , sementara untuk $F_{\text {hitung }}$ diperoleh nilai sebesar 14,895. Sehingga diperoleh nilai $\mathrm{F}_{\text {hitung }}=14,895>\mathrm{F}_{\text {tabel }}=3,44$. Berdasarkan tabel Model Summary pada tabel 2 hubungan abu vulkanik terhadap kuat tekan beton menunjukkan nilai Rsquare sebesar 0,575 atau $\mathrm{R}$ sebesar 0,758 . Hal ini dapat disimpulkan bahwa abu vulkanik berpenganruh kuat terhadap kuat tekan beton.
Sebaran data untuk pengaruh abu vulkanik terhadap kuat tekan beton dapat dilihat pada gambar 4 berikut ini:

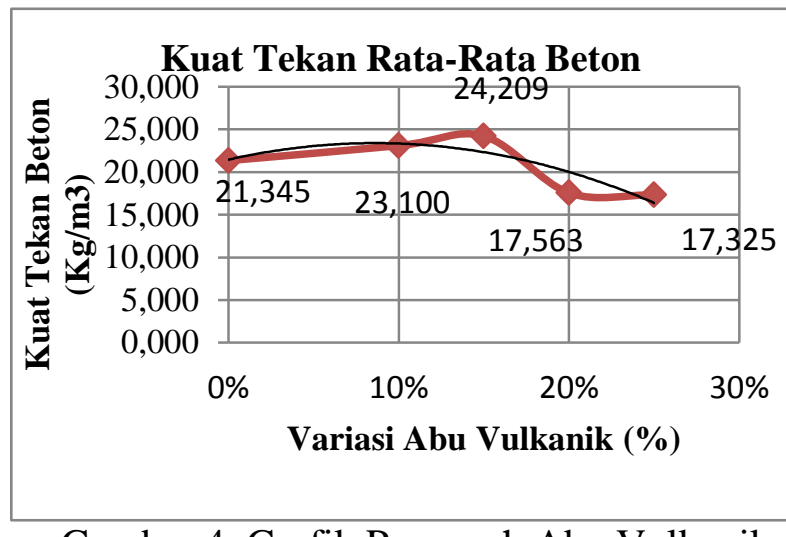

Gambar 4. Grafik Pengaruh Abu Vulkanik terhadap Kuat Tekan Beton

Berdasarkan tabel 2 dan gambar 3 pengaruh penggantian abu vulkanik terhadap kuat tekan beton diperoleh persamaan regresi non linier atau kuadratik, $\mathrm{y}=21,484$ $+0,418 x-0,025 x^{2}$. Dari persamaan tersebut diperoleh nilai kuat tekan optimal sebesar 23,231 MPa pada persentase penggatian abu vulkanik $8,36 \%$.

Dari gambar 3 menunjukkan bahwa pengaruh penggantian abu vulkanik terhadap kuat tekan beton, pada variasi penggantian $8,36 \%$ kuat tekan beton mencapai batas maksimal. Kuat tekan beton mulai menurun setalah penggantian abu vulkanik pada variasi $8,36 \%$ sampai $25 \%$. Hal ini disebabkan karena sifat gradasi abu vulkanik yang halus menyebabkan ikatan antara pasir, 
abu vulkanik, kerikil dengan semen berkurang.

Hasil pengujian berat jenis beton dengan uji linieritas dengan menggunakan program komputer statistik SPSS 16.0 dapat diringkas pada tabel 3 dan gambar 4 berikut ini:

Tabel 3. Hasil Uji Regresi Berat Jenis Beton

\section{Model Summary and Parameter Estimates}

Dependent Variable: Berat Jenis Beton

Model Summary

Parameter Estimates Model Summary pada tabel 3 hubungan abu

$\mathrm{R}$

$\begin{array}{lllllllll}\text { Equation } & \text { Square } & F & \mathrm{df}_{1} & \mathrm{df}_{2} & \text { Sig. } & \text { Constant } & \mathrm{b} 1 & \mathrm{~b} 2\end{array}$

\begin{tabular}{lcccccccc} 
Quadratic & .543 & 13.06 & 2 & 22 & .000 & 2209.016 & 6.96 & - \\
& 6 & & & & & 7 & .293 \\
\hline
\end{tabular}

The independent variable is variasi penggantian abu vulkanik.

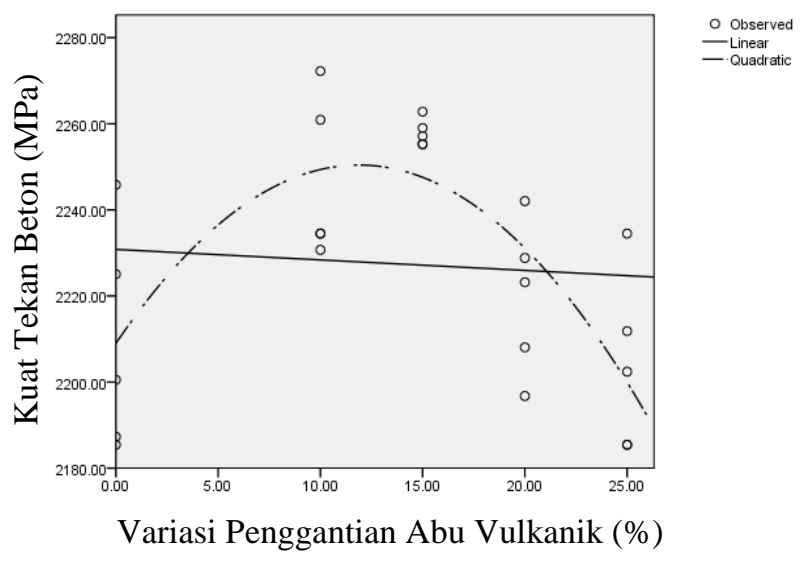

Gambar 4. Pengaruh Penggantian Abu Vulkanik Gunung Kelud terhadap Berat Jenis Beton

Berdasarkan tabel 3 dan gambar 4, diperoleh hubungan variasi penggantian abu vulkanik dan kuat tekan beton bernilai signifikan sebesar $0,000<0,05$ yang berarti bahwa data non linier. Untuk keberartian regresi diperoleh $\mathrm{F}_{\text {tabel }}$ dengan taraf kesalahan $5 \%, \mathrm{df}_{1}=2$ dan $\mathrm{df}_{2}=22$ sebesar 3,44, sementara untuk $F_{\text {hitung }}$ diperoleh nilai sebesar 13,066. Sehingga diperoleh nilai $F_{\text {hitung }}=13,066>F_{\text {tabel }}=3,44$. Maka dapat diartikan bahwa pengaruh penggantian abu vulkanik terhadap berat jenis beton berpengaruh signifikan dan persamaan regresi dapat digunakan. Berdasarkan tabel vulkanik terhadap berat jenis beton menunjukkan nilai Rsquare sebesar 0,543 atau $\mathrm{R}$ sebesar 0,737. Hal ini dapat disimpulkan bahwa abu vulkanik berpengaruh kuat terhadap berat jenis beton.

Sebaran data untuk pengaruh abu vulkanik terhadap kuat tekan beton dapat dilihat pada gambar 5 berikut ini:

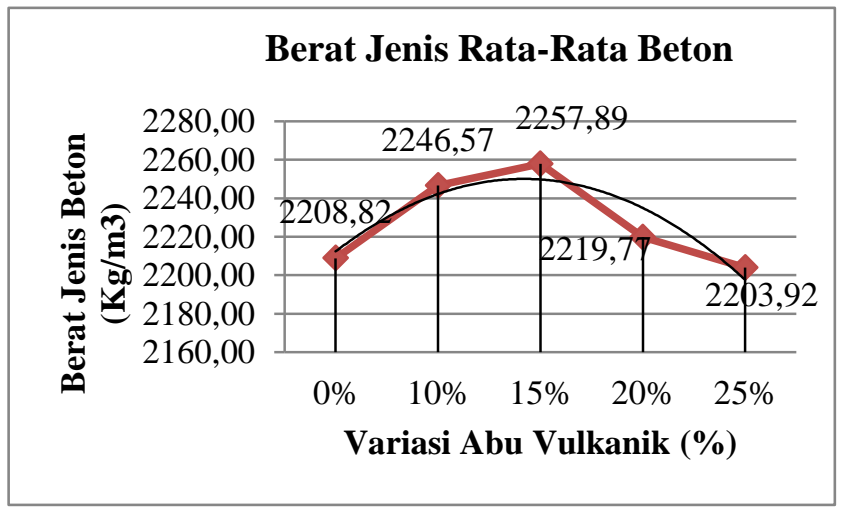

Gambar 5. Hubungan antara Persentase Abu Vulkanik dengan Berat Jenis Beton 
Berdasarkan tabel 3 dan gambar 5 hubungan pengaruh penggantian abu vulkanik terhadap kuat tekan beton diperoleh persamaan regresi non linier atau kuadratik, $y=2209,016+6,967 x-0,293 x^{2}$. Dari persamaan tersebut diperoleh nilai kuat tekan optimal sebesar $2250,432 \mathrm{~kg} / \mathrm{m}^{3}$ pada persentase penggantian abu vulkanik 11,889\%. Hal tersebut disebabkan karena abu vulkanik memiliki nilai kepadatan yang cukup tinggi. Dalam hal ini abu vulkanik sangat mempengaruhi berat jenis beton dikarenakan nilai berat jenis suatu benda tergantung dari nilai berat jenis bahan penyusunnya.

Adapun nilai optimal abu vulkanik berdasarkan kuat tekan dan berat jenis beton, sebagai berikut:

1) Kuat Tekan Optimal

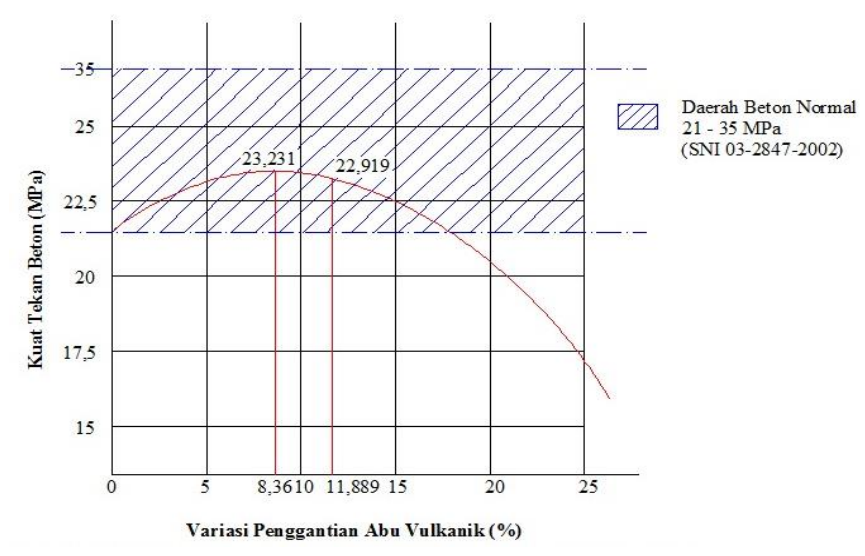

Gambar 6. Variasi Penggantian Abu Vulkanik Optimal pada Kuat Tekan Beton
Berdasarkan gambar 6 di atas menunjukkan bahwa pada persentase kuat tekan optimal $8,36 \%$ variasi penggantian abu vulkanik menunjukkan kuat tekan beton sebesar 23,231 MPa dan pada variasi penggantian abu vulkanik 11,889\% menunjukkan kuat tekan beton sebesar 22,919 MPa. Kuat tekan beton tersebut masuk dalam kategori beton normal yaitu antara 21MPa - 35 MPa. (SNI 03-24872002)

2) Berat Jenis Optimal

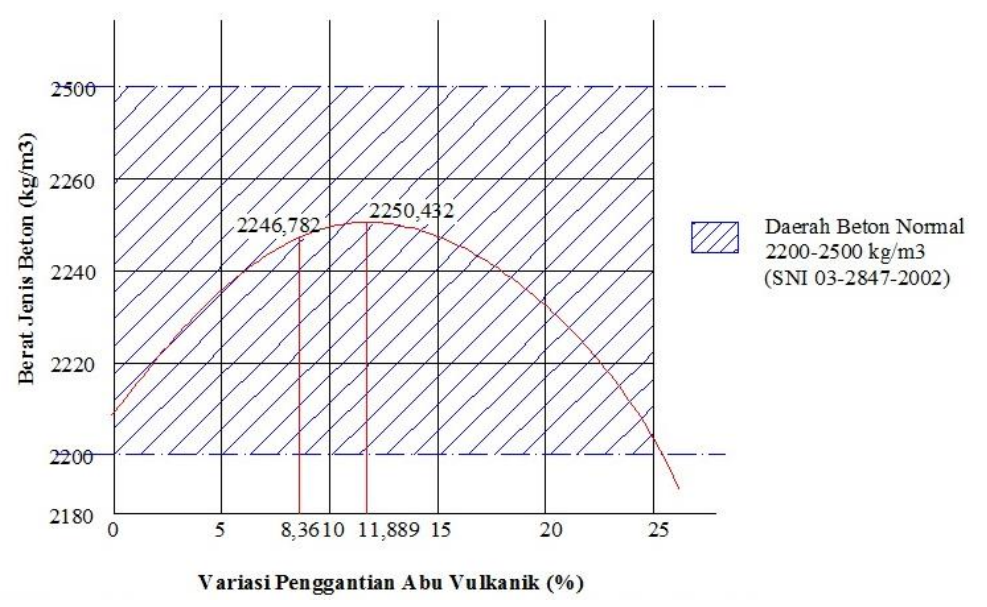

Gambar 7. Variasi Penggantian Abu Vulkanik Optimal pada Berat Jenis Beton

Berdasarkan gambar 7 di atas menunjukkan bahwa pada persentase $8,36 \%$ variasi penggantian abu vulkanik menunjukkan berat jenis beton sebesar $2246,782 \mathrm{~kg} / \mathrm{m}^{3}$ dan pada variasi persentase optimal penggantian abu vulkanik $11,889 \%$ menunjukkan berat jenis beton sebesar 
$2250,432 \mathrm{~kg} / \mathrm{m}^{3}$. Kuat tekan beton tersebut masuk dalam kategori beton normal yaitu antara $2200-2500 \mathrm{~kg} / \mathrm{m}^{3}$. (SNI 03-24872002)

Dari penjelasan di atas dapat disimpulkan bahwa penggunaan abu vulkanik Gunung Kelud sebagai pengganti sebagian agregat halus pada kuat tekan dan berat jenis beton dapat digunakan campuran abu vulkanik dengan variasi abu 11,889\% dengan kuat tekan beton sebesar 22,919 MPa dan berat jenisnya 2250,432 kg/m serta masuk ketegori beton normal. (SNI 032487-2002)

Bahan ajar yang dihasilkan setelah penelitian ini berupa suplemen bahan ajar tentang pemanfaatan abu vulkanik Gunung Kelud unutk pengganti sebagian agregat halus pada beton ditinjau dari kuat tekan dan berat jenis beton. Penyusunan bahan ajar ini disesuaikan dengan silabus mata kuliah teknologi beton dan disesuaikan dengan standar kompetensi dan kompetensi dasar.

1. Standar kompetensi : mendeskripsikan perkembangan, kebaikan dan keburukan, bahan-bahan pembuatan beton, cara pengolahan, perancangan campuran adukan, melakukan evaluasi mutu, pengambilan sampel, dan macam-macam beton yang lain.
2. Kompetensi dasar dan sub kompetensi dasar :mendeskripsikan beton jenis lain.

3. Indikator : menjelaskan beton normal.

\section{SIMPULAN}

Berdasarkan hasil penelitian dan pembahasan tentang abu vulkanik sebagai pengganti sebagian agregat halus terhadap kuat tekan dan berat jenis beton, dapat disimpulkan bahwa:

1. Variasi penggantian abu vulkanik berpengaruh kuat dan berpengaruh positif terhadap kuat tekan, di mana abu vulkanik sebagai agregat halus akan mengakibatkan peningkatan kuat tekan beton pada variasi penggantian abu vulkanik $0 \%$ hingga $15 \%$ dan mengakibatkan penurunan kuat tekan pada variasi abu vulkanik $20 \%$ hingga $25 \%$.

2. Variasi penggantian abu vulkanik berpengaruh kuat dan berpengaruh positif terhadap berat jenis, di mana abu vulkanik sebagai agregat halus akan mengakibatkan peningkatan berat jenis beton pada variasi penggantian abu vulkanik $0 \%$ hingga $15 \%$ dan mengakibatkan penurunan kuat tekan pada variasi abu vulkanik $20 \%$ hingga $25 \%$.

3. Nilai optimal kuat tekan beton terdapat pada variasi abu vulkanik $8,36 \%$ sebesar 
23,231 MPa masuk kategori beton normal yaitu antara $21 \mathrm{MPa}-35 \mathrm{MPa}$.

4. Nilai optimal berat jenis beton terdapat pada variasi abu vulkanik 11,889\% sebesar $2250,432 \mathrm{~kg} / \mathrm{m}^{3}$ masuk kategori beton normal yaitu antara $2200-2500$ $\mathrm{kg} / \mathrm{m}^{3}$.

5. Nilai campuran beton yang optimal yaitu pada variasi abu vulkanik 11,889\% yaitu dengan kuat tekan beton sebesar 22,919 MPa dan berat jenisnya $2250,432 \mathrm{~kg} / \mathrm{m}^{3}$.

6. Bahan ajar yang dihasilkan setelah penelitian ini berupa suplemen bahan ajar tentang pemanfaatan abu vulkanik gunung Kelud untuk pengganti sebagian agregat halus pada beton normal ditinjau dari kuat tekan dan berat jenis beton.

\section{SARAN}

Berdasarkan simpulan hasil penelitian dimuka, maka dapat dikemukakan saransaran sebagai berikut:

1. Perlu adanya penambahan sampel benda uji beton untuk penelitian selanjutnya agar hasil lebih akurat dan dapat menjadi referensi untuk industri beton.

2. Mohon dipilih mix design yang menyertakan perhitungan kadar air abu vulkanik.
3. Perlu adanya pengembangan pengujian beton menggunakan abu vulkanik selain uji kuat tekan dan berat jenis beton.

4. Perlu adanya pengujian penambahan abu vulkanik pada beton ringan.

\section{DAFTAR PUSTAKA}

Anonim. 1989. Standar Nasional Indonesia 03-0349-1989: Bata Beton untuk Pasangan Dinding. Dewan Standarisasi Nasional. 1989. Standar Nasional Indonesia S-04-1989-F: Spesifikasi Bahan Bangunan Bagian A. Dewan Standarisasi Nasional. . 2002. Standar Nasional Indonesia

03-2847-2002: $\quad$ Tata Cara Perhitungan Struktur Beton untuk Bangunan Gedung. Dewan Standarisasi Nasional.

Baihaqi, Ahmad. 2007. Penggunaan Abu Vulkanik sebagai Bahan Campuran Pembuatan Beton fc' $30 \mathrm{MPa}$ dengan Persentase 0\%, 10\%, 15\%,20\% dan 25\%. Skripsi Tidak Dipublikasikan. Surabaya: FTSP - ITS.

Bayuseno. 2010. Sintesis Semen Geopolimer Berbahan Dasar Abu Vulkanik dari Erupsi Gunung Merapi. Semarang: Undip.

Ghozali, Imam. 2011. Aplikasi Analisis Multivariate dengan Program IBM SPSS 16,0 Edisi. Semarang: Universitas Diponegoro. 
Kurniawan, Candra, Perdamean S., dan Muljadi. 2011. Jurnal Ilmu Pengetahuan dan Teknologi Telaah "Pembuatan Beton High-Strenght Berbasis Mikrosilika dari Abu Vulkanik Gunung Merapi". Jakarta: Pusat Penelitian Fisika - LIPI.

Nugraha,Paul dan Antoni. 2007. TEKNOLOGI BETON dari Material, Pembuatan, ke Beton Kinerja Tinggi. Yogyakarta : Andi Offset.

Pannen, P dan Purwanto. 2001. Penulisan Bahan Ajar. Jakarta: Pusat antar Universitas untuk Peningkatan dan Pengembangan Aktivitas Instruksional Ditjen Dikti Diknas.

Raju, N. Khrisna. 1983. Design Of Concrete Mixes. Delhi (India): Orient Offset.

Tjokrodimuljo, Kardiyono. 2004. Teknologi Beton. Yogyakarta: Jurusan Teknik Sipil, Fakultas Teknik Universitas Gajah Mada. 